\title{
SEEKING MORE THAN TRUTH: \\ A RATIONALIZATION OF THE PRINCIPLED EXCEPTION TO THE HEARSAY RULE
}

\author{
SHAWN MOEN*
}

Canadian treatment of hearsay evidence has changed significantly in the preceding 20 years. Since 1990, the Supreme Court of Canada has adopted a more flexible approach to hearsay evidence through the development of the "principled exception." In this article, the author examines the purpose of evidence law and trial procedure from three different perspectives: as a tempered "truth-seeking" process, as a medium to communicate the acceptability of verdicts, and as a tool to regulate the epistemic and ethical conduct of decision-makers. He suggests that these three purposes are complementary and examines the principled exception to the hearsay rule using this pluralist approach. Overall, the author concludes that while the principled exception is primarily directed at promoting "truth-seeking," the necessity criterion and the current procedural format are also designed to enhance the communicative role of the trial process and to assist in the deliberation by the adjudicator. As such, the principled approach has been designed to seek more than the "truth."
Au Canada, l'importance du ouï-dire a considérablement changé au cours des derniers 20 ans. Depuis 1990, la Cour suprême du Canada a adopté une approche plus souple à la prévue par ouï-dire grâce au développement «d'une exception fondée sur des principes». Dans cet article, l'auteur examine la raison d'être du droit de la preuve et de la procédure qui régit un procès de trois points de vue différents : comme un processus modéré «à la recherche de la vérité», comme moyen de communiquer l'acceptabilité des verdicts et comme outil pour la conduite épistémique et éthique des décideurs. Il laisse penser que ces trois raisons d'être se complètent et il examine l'exception fondée sur des principes à la règle du ouï-dire en utilisant cette approche pluraliste. Dans l'ensemble, l'auteur conclut qu'alors que l'exception fondée sur des principes vise essentiellement «la recherché de la vérité», le critère de la nécessité et le format actuel des procédures sont également conçus de manière à améliorer le rôle communicatif du procès et d'aider à la délibération par l'arbitre. En soi, l'exception fondée sur des principes a été conçue pour chercher plus que «la vérité».

\section{TABLE OF ConTENTS}

I. IntRODUCTION . . . . . . . . . . . . . . . . . . . . . . . . . . . . . . . . . 754

II. Perspectives on the Purpose of Evidence LaW . . . . . . . . . . . 755

A. EVIDENCE LAW AND THE Tempered PuRsuit of TRuth $\ldots \ldots .755$

B. Communication, the Trial Process, AND EVIDENCE LAW . . . . . . . . . . . . . . . . . . . . . . . . . 757

C. EVIDENCE LAW From THE PERSPECTIVE

OF THE AdJUDICATOR . . . . . . . . . . . . . . . . . . . . . . . . . 759

D. A PluRALIST APPROACH TO

EVIDENCE LAW THEORY . . . . . . . . . . . . . . . . . . . . . . 760

III. The PRINCIPLED EXCEPTION TO THE HEARSAy Rule . . . . . . . . . . . 761

A. The ReLIABILITy CRITERION AND “Truth-SEEKING” . . . . . . . . 762

B. Rationalizing THE NECESSITY CRITERION $\ldots \ldots \ldots \ldots \ldots \ldots 765$

C. The Relevance of the Voir Dire Procedure $\ldots \ldots \ldots \ldots . \ldots 768$

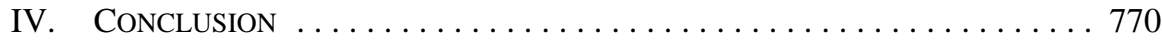

Practising lawyer, Saskatoon, Saskatchewan; LL.B.(Sask.), LL.M.(Osgoode). This article was prepared during my graduate studies at Osgoode Hall Law School. Thanks are owed to Professor Francois Tanguay-Renaud for his helpful comments made during its research and completion. 


\section{INTRODUCTION}

The potential role of hearsay evidence in the Canadian criminal trial has been enhanced in recent years. Historically, hearsay statements have been considered generally inadmissible in evidence unless falling under one of the narrowly defined exceptions allowing admission. The reason for this general exclusionary rule has been that an adjudicator ${ }^{1}$ has a uniquely difficult time assessing the reliability of hearsay evidence because of its nature as an out-ofcourt, untested statement. Since 1990, the Supreme Court of Canada has taken an increasingly flexible approach to the admission of hearsay evidence in a criminal trial, allowing the admission of hearsay by the trial judge under the "principled exception."2 The development of the principled exception is said to be part of a general trend in Canadian evidence law, where technical rules of exclusion are being replaced by context-based rules that allow for the exclusion of evidence only when there are compelling reasons to exclude. ${ }^{3}$ Some commentators have described this development as revolutionary. ${ }^{4}$

This article attempts to understand the Supreme Court's principled exception by considering several perspectives in evidence law theory. Part II describes three such perspectives: (1) the so-called "Rationalist Tradition," which primarily explains rules of evidence and trial procedure by the extent to which they facilitate an adjudicator's search for "true facts"; (2) the purpose of evidence law and trial procedure as a communicative medium, designed to deliver verdicts that are acceptable to the accused person and the general public; and (3) the purpose of evidence law in promoting the epistemic and ethical justification for the deliberation and eventual verdict of an adjudicator. This article prefers a pluralist approach to evidence law theory, arguing that joint consideration of these three, complementary perspectives gives a more robust understanding of specific rules of evidence.

Informed by that pluralist perspective, Part III critically examines the development of the principled exception to the hearsay rule by considering its evolution in Supreme Court jurisprudence. One observes that the Supreme Court's decisions have been almost exclusively devoted to developing a flexible, contextual approach to assessing the reliability of hearsay evidence, so as to facilitate the "truth-seeking" function of the trial process. Conversely, the requirement of necessity and the relevant procedural rules, elements this article suggests are only loosely connected to a truth-seeking purpose of evidence law, have received very little explanation by the Court. As a result of its focus on the assessment of reliability, one could conclude that the Supreme Court, through its development of the principled hearsay exception, has adopted a perspective of evidence law as being solely devoted to facilitating truth-seeking. This, however, provides an incomplete rationalization of the principled exception. While the principled exception is perhaps primarily directed at promoting truth-seeking, consideration under the pluralist perspective suggests that the

1 In a Canadian criminal trial, the entity responsible for fact-finding and the ultimate delivery of a verdict can, alternatively, be a trial judge sitting alone or a jury. For ease of reference, this article refers to that entity as an "adjudicator."

2 The "principled exception" in criminal law has its roots in the civil case of Ares v. Venner, [1970] S.C.R. 608.

3 David M. Paciocco, "Evidence About Guilt: Balancing the Rights of the Individual and Society in Matters of Truth and Proof” (2001) 80 Can. Bar Rev. 433 at 441.

$4 \quad$ Hamish Stewart, “Justice Frank Iacobucci and the Revolution in the Common Law of Evidence” (2007) 57 U.T.L.J. 479 at 479 . 
necessity criterion and the current procedural format are also designed to enhance the communicative role of the trial process and to assist in the deliberation by the adjudicator. In that sense, the development of an increased flexibility to admit hearsay evidence under the principled approach has involved much more than developing a more effective search for "truth."

\section{Perspectives on the Purpose of Evidence LaW}

\section{A. EVIDENCE LAW AND The TeMPered Pursuit OF Truth}

It is perhaps both uncontroversial and intuitively attractive to suggest that a purpose of the criminal trial process, and its related rules of evidence, is to assist in the collection and recognition of the truth. ${ }^{5}$ This conception of the trial as a "truth-seeking process" has received explicit endorsement by prominent members of the Canadian judiciary. As one example, Cory J. observed that "[a] true verdict reached upon properly admissible evidence must be the goal of all court proceedings.” " As another example, L’Heureux-Dubé J. opined that "the pre-eminent role of the trial is to ascertain the truth."7 One also expects that this perspective would find immediate and intuitive favour with the common layperson, as is suggested when significant media attention and public resources are devoted to investigating instances when accused persons are found to have been wrongfully convicted or when there is public outcry and complaint when an accused person is found not guilty by reason of a perceived "technicality." In that sense, the reliability of a trial system is generally thought of in reference to the extent that it produces findings that are factually correct. ${ }^{8}$ Indeed, the trial system is thought to be broken when it is perceived to have not resulted in the discovery and recognition of the truth.

Evidence law scholarship has been similarly influenced by the idea that the trial process and its rules of evidence are, or should be, primarily designed to facilitate the discovery of truth by the adjudicator. William Twining defines this perspective in the literature as the "Rationalist Tradition," suggesting that many evidence law scholars have drawn from Jeremy Bentham's central thesis that "the direct end of adjective law is rectitude of decision, that is the correct application of valid laws (presumed to be consonant with utility) to true facts." The purpose and value of evidence law is said to be in its facilitative role, insofar that it facilitates the enforcement of substantive legal rules by regulating the manner in which facts are proven and enabling the correct application of law to true facts. ${ }^{10}$ It is in that sense that some consider, as Bentham did, that "[e]vidence is the basis of justice."11

This article does not attempt to discuss whether the achievement of an objective truth is possible in a criminal trial. Rather, this article takes the position that, regardless of whether objective truth is possible, the trial system, for the reasons outlined in this section, must have as one of its purposes the discovery of objective truth.

R. v. B. (K.G.), [1993] 1 S.C.R. 740 at 822 [K.G.B.].

R. v. Hawkins, [1996] 3 S.C.R. 1043 at 1102 [Hawkins].

H.L. Ho, "Justice in the Pursuit of Truth: A Moral Defence of the Similar Facts Rule" (2006) 35 C. L. World Rev. 51 at 53 [Ho, "Justice in the Pursuit of Truth"].

William Twining, Rethinking Evidence: Exploratory Essays, 2d ed. (New York: Cambridge University Press, 2006) at 41 [emphasis added].

Paciocco, supra note 3 at 436.

Twining, supra note 9 at 42, citing Jeremy Bentham, The Works of Jeremy Bentham, ed. by John Bowring (New York: Russell \& Russell, 1962) vol. 7 at 384. 
Placing a high value on the "rectitude of decision" has fostered a debate as to how the law of evidence can best facilitate an adjudicator's discovery of true facts. Some, like Bentham, advocate for a system of "free proof," suggesting that all binding rules that exclude relevant evidence should be abolished and the adjudicator should be allowed to exercise a high level of discretion in engaging in rational fact-finding. ${ }^{12}$ Some commentators have further argued that it is immoral to withhold relevant evidence from an adjudicator, arguing that the exclusion of relevant evidence insults the autonomy and rationality of those required to adjudicate. ${ }^{13}$ On the other side of the debate, some commentators argue for increased regulation by evidence law, describing rules of evidence as embodying "the accumulated wisdom of centuries of practical experience and ... fundamental notions of procedural fairness." 14 Some suggest that the regulatory effect of evidence law is necessary to overcome the variety and imperfection of decision-makers and, accordingly, is required with equal force for judges and juries alike. ${ }^{15}$ Others suggest that detailed rules of evidence are necessary to appropriately apportion, between the litigants, the risk of factual error by the adjudicator. $^{16}$

While truth-seeking is considered the primary purpose for evidence law by scholars in the Rationalist Tradition, it is also recognized that truth-seeking is not the only legitimate purpose for evidence law. Indeed, as Twining suggests, many of those scholars, including Bentham and other advocates of "free proof," recognize that the proper construct of the law of evidence also involves a balancing of societal values. The pursuit of truth was to be given a "high, but not necessarily an overriding, priority in relation to other [societal] values" and, on occasion, societal values could override the pursuit of truth as a purpose for evidence law. ${ }^{17}$ David Paciocco describes these rules as "rules of subordinated evidence" and describes the circumstance as one where the "law makes its choice between competing values." ${ }^{18}$ As one example, our society places significant value in preserving the sanctity of a marital relationship. As a result, communication between married couples is privileged, ${ }^{19}$ and the spouse of an accused person is neither compellable nor competent as a Crown witness during the prosecution of that accused person, save in cases involving that spouse's liberty or health and other defined circumstances. ${ }^{20}$ While that spouse may have information that is highly probative and perhaps conclusive to the matter before the court, the value society places in the sanctity of the marital relationship takes priority over the societal value we place in truthseeking. Other examples include the imposition of privilege over communications between a solicitor and her client and the right of the accused person against self-incrimination.

In addition to balancing societal values, otherwise probative and relevant evidence may also be excluded to promote the efficient management of the trial process, under what

Twining, ibid. at 199-200.

Todd E. Pettys, "The Immoral Application of Exclusionary Rules” (2008) Wis. L. Rev. 463.

Twining, supra note 9 at 200.

Frederick Schauer, "In Defense of Rule-Based Evidence Law — and Epistemology Too" (2008) 5 Episteme 295.

Alex Stein, Foundations of Evidence Law (New York: Oxford University Press, 2005) at 133.

Supra note 9 at 76.

Supra note 3 at 438, citing The Honourable Samuel Freedman, "Admissions and Confessions" in Roger E. Salhany \& Robert J. Carter, eds., Studies in Canadian Criminal Evidence (Toronto: Butterworths, 1972) 95 at 99.

19 Canada Evidence Act, R.S.C. 1985, c. C-5, s. 4(3).

20 R.v. Couture, 2007 SCC 28, [2007] 2 S.C.R. 517 at paras. 41-43 [Couture]. See also ibid., ss. 4(2), 4(4). 
Paciocco terms "rules of practical exclusion."21 Twining describes these types of rules as a balance between the truth-seeking purpose and the just, efficient management of the trial process:

One crucial basis for evaluating “fact-finding” institutions, rules, procedures and techniques is how far they are estimated to maximize accuracy in fact-determination - but other criteria such as speed, cheapness, procedural fairness, humaneness, public confidence and the avoidance of vexation for participants are also to be taken into account. ${ }^{22}$

Evidence law occasionally allows litigants to depart from the traditional means of proving facts by viva voce evidence partly because the alternate method is considered reliable, but also to increase the efficiency of the trial process. For example, Canadian evidence law allows for the admission of business records under s. 30 of the Canada Evidence Act ${ }^{23}$ and for the admission of a certificate of analysis under s. 258 of the Criminal Code. ${ }^{24}$ An efficient, focused trial enables the adjudicator to more effectively manage the information before it and to more expeditiously render a correct verdict based on reliable evidence.

As noted at the outset of this section, there is perhaps both intuitive appeal and considerable merit in suggesting that the primary purpose of a criminal trial and its rules of evidence is the pursuit of "truth." "[T]ruth is pursued for the sake of justice, where justice is primarily understood as the correct application of law to true findings of fact." 25 An adjudicative system that does not place general priority on the discovery of the truth would be considered unjust. While recognizing the primacy of truth-seeking as a purpose for evidence law, the Rationalist Tradition has also long recognized "rules of subordinated evidence” and "rules of practical exclusion.” These rules, on occasion, necessarily derogate from the truth-seeking purpose of the criminal trial. In the Rationalist Tradition, therefore, the discovery of the "truth" has only been a tempered, albeit important, purpose of the criminal trial process. Considering truth-seeking as a tempered, although primary, purpose of evidence law is reinforced when one considers the communicative purpose of the criminal trial and considers the criminal trial from the perspective of the adjudicator.

\section{B. Communication, the Trial Process, and Evidence law}

Considering the broader purpose of a criminal trial in society suggests that the trial procedure and its rules of evidence may be designed to facilitate more than a tempered pursuit of truth. Adjudicators do not simply weigh admissible evidence as an academic exercise. The criminal trial process is a public process. Following their determination of true facts, adjudicators are expected to publicly render a verdict as to whether the conduct of the accused was in compliance with or contrary to the law, and are required to give reasons for that verdict. ${ }^{26} \mathrm{~A}$ criminal conviction denounces the conduct of the accused person by publicly

Supra note 3 at 438 .

Supra note 9 at 76.

Supra note 19.

R.S.C. 1985 , c. C-46.

H.L. Ho, A Philosophy of Evidence Law: Justice in the Search for Truth (New York: Oxford University Press, 2008) at 48 [Ho, A Philosophy of Evidence Law].

26 The obligation to give reasons is said to be owed to both the accused and the public at large: see $R$. $v$. Sheppard, 2002 SCC 26, [2002] 1 S.C.R. 869 at para. 55. 
declaring that conduct to be illegal. Through that public denouncement, the adjudicator attempts to dissuade the convicted offender and others from engaging in similar conduct or behaviour. $^{27}$

Within this context, the question becomes why individuals, perhaps most importantly the accused person, should be expected to accept the authority of a trial verdict in denouncing certain behaviours. R.A. Duff argues that the proper purpose of a system of law is "that citizens should not merely obey its demands, but should accept, as justified, the obligations which it imposes on them." ${ }^{28}$ Accordingly, Duff posits that, by subjecting an accused person to a criminal trial and potentially declaring that an accused person's conduct was criminal, the adjudicator engages the accused person in conversation as a "rational and responsible agent" who can understand and accept the justification of the verdict, rather than attempting to coerce the accused person's conduct into compliance through punitive orders. ${ }^{29}$ In that sense, the adjudicator seeks the assent of the accused person to the judgment expressed by the adjudicator. ${ }^{30}$ The structures and procedures associated with a trial must be "consistent with [that] communicatory and justificatory purpose” for that communicative function to be effective. ${ }^{31}$ In other words, to effectively convince an accused person to follow the verdict delivered by an adjudicator, as a rational and responsible person capable of persuasion, the procedures and rules related to the criminal trial must also be based on rationality. Accordingly, rules of evidence may be designed with the purpose of assisting the adjudicator in explaining to an accused person why the verdict is acceptable and worthy of compliance.

The criminal process serves a broader purpose than simply communicating and explaining the verdict to that specific accused person. As noted, a criminal verdict is declared publicly. This public aspect is also intended to engage the general public in conversation regarding the appropriateness of the accused person's behaviour and to encourage citizens to "assimilate legal rules into their [own] behavior." 32 Charles Nesson argues that, while most commentators prefer to rationalize evidentiary and procedural rules as a means for advancing the search for truth, many of the procedures of our legal system are best understood as means for promoting public acceptance of verdicts and, in turn, public acceptance of behavioural messages. ${ }^{33}$ Nesson suggests that, if the legal system is to successfully project the legal rule and related behavioural messages to the public, the fact-finding process used by the adjudicative body must be capable of projecting the verdict as a "statement of an event" rather than a "statement of proof." 34 The adjudicative body must be able to explain to the public that "this is the type of conduct that happened" rather than "this is the type of conduct that was proven.”

The trial process preserves its authority in characterizing a verdict as a "statement of an event” by assuring the public that it had access to the most reliable sources of evidence. A

R.A. Duff, Trials and Punishments (New York: Cambridge University Press, 1986) at 125.

Ibid.

Ibid. at 99.

Ibid. at 126.

Ibid. at 127.

Charles Nesson, "The Evidence or the Event? On Judicial Proof and the Acceptability of Verdicts" (1985) 98 Harv. L. Rev. 1357 at 1359.

Ibid. at $1368-69$.

Ibid. at 1358 . 
verdict of guilty or not guilty is only undermined to the extent that the public has an independent basis for believing that the verdict is factually incorrect. Rules of evidence, therefore, are effective in furthering the public communicative function of the criminal trial process when they minimize the independent sources of fact that could credibly undermine the verdict. While Nesson has been criticized as promoting a legal system that is not genuine in its search for truth, ${ }^{35}$ Nesson's explanation, when considered alongside the tempered truthseeking purpose of evidence law, can assist in explaining why certain evidentiary rules are structured in a specific manner. The communication of trial verdicts and behavioural messages to the public and the accused person is an important aspect of the criminal trial process. While rules of evidence may have truth-seeking as their primary purpose, the role of those rules in assisting that communicative function may explain their specific design.

\section{EVidence LAW From the Perspective of THE Adjudicator}

By rationalizing rules of evidence with reference to their tempered truth-seeking and communicative purposes, one considers the function of the trial system from an external perspective. That is, both approaches analyze rules of evidence from the standpoint of the detached observer or the "system engineer," in terms of their impact on the outcome of factfinding and verdict delivery. ${ }^{36}$ Trial procedures and rules of evidence can also be considered from the "internal" perspective of the adjudicator, to the extent that they interact with the process of trial deliberation. A person whose case is before the court is not merely entitled to an application of substantive law to true facts, to a trial procedure rationally constructed to assist in the pursuit of truth, or to an acceptable communication of the trial verdict. ${ }^{37}$ Rather, conduct of the trial and deliberation by the adjudicator must be both epistemologically and morally justified to that individual adjudicator. ${ }^{38}$ As put by H.L. Ho, a "court must not only pursue truth to do justice, it must also do justice in pursuing truth." 39

First, an adjudicator must subjectively enjoy epistemic justification for their positive findings. Ho suggests that an adjudicator faces this key normative question during the course of deliberation: "Given the evidence available on this disputed proposition of fact, is one justified in judging it true?" 40 Independent of whether a conclusion is objectively justifiable, Ho argues that the adjudicator must subjectively believe that a rational argument exists supporting their verdict on the evidence tendered. ${ }^{41}$ Indeed, in addition to promoting the rationality of the deliberative process and, in that sense, being a value in itself, subjective justification may also enhance the truth-seeking purpose of the criminal trial. Personally rationalizing one's deliberations may help “force out ... obscurity[,] fallacious reasoning, questionable assumptions, unsubstantiated conclusions, unfair prejudices, and other wrongs and defects that might otherwise go undetected in trial deliberation." 42

Ho, A Philosophy of Evidence Law, supra note 25 at 60. Ibid. at 46.

Ho, "Justice in the Pursuit of Truth," supra note 8 at 55.

Ho, A Philosophy of Evidence Law, supra note 25 at 71.

Ho, "Justice in the Pursuit of Truth," supra note 8 at 55.

Ho, A Philosophy of Evidence Law, supra note 25 at 71.

Ibid. at 72.

Ibid. at 76 [footnotes omitted]. 
While rules of evidence are traditionally thought of as performing an exclusionary function, evidence law can also assist the deliberation of the adjudicator and thereby promote subjective justification by operating "at the 'meta-level' of evidential reasoning." 43 A rule of evidence can provide guidance to the adjudicator by explaining how classes of evidence that may be qualitatively different should be used during deliberation, whether that specific evidence rule suggests the drawing of inferences, excludes pieces of evidence from deliberation, or allows for admission but prohibits a specific use of a piece of evidence. ${ }^{44}$ Rules of evidence can be structured in a way to promote the subjective justification of an adjudicator and, in turn, a rational approach to the body of evidence at trial.

In addition to deliberating in a subjectively justifiable manner, an adjudicator's decision must also be ethically justified. Parties enjoy "a right to a just verdict, where justice must be understood to impose ethical demands on the manner in which the court conducts the trial, and importantly, on how it deliberates on the verdict." 45 Ho argues that the court, in rendering a verdict, must acquire the moral authority to require acceptance of that verdict, a concept that is different from assessing the acceptability of that verdict from the perspective of the accused person or the public:

The court must strive, in the manner in which it reaches the verdict, to acquire the moral authority to say to the parties that they should accept it, even or especially when it affects them adversely. This is not to promote justice and fairness as means of obtaining de facto acceptance of the verdict; if that be our goal, we need only to promote the appearance of justice and fairness. It is at once far simpler and more powerful to say: the factfinder ought to be just and fair to the parties because, as a person, she ought to care about justice and fairness to her fellow human beings. 46

Justice in trial deliberation requires that the adjudicator acknowledges the humanity of the accused person, expresses adequate respect and concern, and responds to the subject matter with empathic care. ${ }^{47}$ As such, the encouragement of a rational and ethical approach to trial conduct and deliberation may be a further purpose of specific rules of evidence.

\section{A Pluralist Approach to EVIDENCE LAW Theory}

Different perspectives have been taken of the purpose of evidence law and trial procedure. While each perspective has some merit when explaining the purpose of evidence law, the described purposes have difficulty as stand-alone purposes. For example, a verdict may be a correct application of law to true facts and in that sense a factually correct verdict, but if it is not communicated in an acceptable fashion, justice is perceived by the accused person or by the public as having not been carried out. Moreover, a verdict can be communicated in a fashion that is accepted by the public, but if it is later revealed that the verdict is factually incorrect or that the adjudicator acted unethically by, for example, disbelieving the accused based on her ethnicity, we consider that verdict to be an affront to the purposes of the trial system and our conception of justice. Finally, an adjudicator may be subjectively

Ho, “Justice in the Pursuit of Truth,” supra note 8 at 56.

Ibid. at 57.

Ho, A Philosophy of Evidence Law, supra note 25 at 79.

Ibid. at 81 [footnotes omitted].

Ibid. at 83 . 
rational and ethical, but their verdict may be factually incorrect or the manner in which they conducted the trial does not adequately communicate that verdict. Again, that specific verdict may be owed little deference by the accused person or the public and may foster concerns as to whether the trial system is functioning properly.

Rather than operating as independent purposes, the three perspectives are, instead, complementary. It is better to consider evidence law as having a variety of interacting purposes: as a primary, though tempered, truth-seeking process that balances societal values, as a medium to communicate the acceptability of verdicts, and as a tool to regulate the epistemic and ethical conduct of decision-makers. This pluralist perspective accords more closely with broad concepts such as natural justice and trial fairness. A system where adjudicators strive for objective truth, attempt to balance competing societal interests, effectively communicate their verdicts to the accused and the public alike, and attempt to justify their decisions from an ethical and epistemological standpoint is a system that attempts to place fairness and justice at its forefront. On a more micro level, the pluralist perspective provokes a more robust understanding as to the design of specific rules of evidence. In that final sense, the remainder of this article examines the principled exception to the hearsay rule using this pluralist approach.

\section{The Principled EXCEPTION TO THE HeARSAy RULE}

Prior to 1990, Canadian evidence law prohibited the admission of hearsay evidence unless it fell under a recognized, strictly defined exception. To understand the rationale for this general rule of inadmissibility, it is helpful to consider the nature of hearsay evidence in relation to the typical trial process. Ordinarily, witnesses in a criminal trial testify in person before the adjudicator. When a party attempts to tender hearsay evidence, that party has attempted to tender a statement that has been made out-of-court and asks the adjudicator to rely upon that statement for the truth of its contents. As Charron J. explained in $R$. $v$. Khelawon, "[o]ur adversary system puts a premium on the calling of witnesses, who testify under oath or solemn affirmation, whose demeanour can be observed by the trier of fact, and whose testimony can be tested by cross-examination. We regard this process as the optimal way of testing testimonial evidence." ${ }^{48}$ Hearsay statements pose unique difficulties for an adjudicator testing the reliability of that form of evidence, primarily because the adjudicator is unable to assess the demeanour of the declarant, the statement may not be made under oath or solemn affirmation, and the declarant typically has not been subjected to crossexamination during the making of that statement. The ordinary safeguards that we enjoy with respect to viva voce evidence are not present when hearsay evidence is tendered.

Accordingly, hearsay evidence was traditionally excluded from evidence unless falling under one of the strictly defined exceptions allowing for admission. In Canada, there are several exceptions to this general exclusionary rule under both the common law and statute, including the res gestae or spontaneous utterance exception, the dying declaration exception, the statement of intention exception, the business records exception, and exceptions allowing for the admission of certificates of analysis in impaired driving and drug prosecutions. ${ }^{49}$ In 
addition to minimizing instances when an adjudicator may rely on unreliable evidence, the general exclusionary rule and its exceptions also had the value of certainty and trial efficiency, as the parties could reasonably predict whether a specific piece of hearsay evidence would be admitted for the truth of its contents. However, by using a strict, categorical approach, the traditional approach to hearsay evidence could on occasion result in the exclusion of probative and otherwise reliable hearsay evidence if it was not subject to one of the defined exceptions.

In 1990, the Supreme Court of Canada began a gradual move away from the traditional approach to the exclusion of hearsay evidence towards a more contextual approach of assessing such evidence. Hearsay evidence is now admissible under the principled exception if it is both "reliable" and "necessary," criteria that are assessed by the trier of law prior to admission of the evidence for consideration by the trier of fact. Through its development of the requirement of reliability, the Supreme Court can be considered to have placed explicit priority in the truth-seeking purpose of evidence law. However, the requirement of necessity and the voir dire procedure can only be fully understood when one considers the purpose of evidence law as both a communicative medium and as a means of regulating the epistemic and ethical deliberation of the adjudicator.

\section{A. The Reliability CRITERION AND “Truth-SEEKING”}

The principled exception to the hearsay rule has its birthplace in the criminal law context in the Supreme Court of Canada decision in $R$. v. Khan.$^{50}$ Dr. Khan was a medical doctor charged with sexually assaulting a three and a half year old patient by putting his penis in her mouth. The child was not competent to give sworn evidence. The Crown evidence consisted almost entirely of an out-of-court statement made by the child to her mother, where she disclosed that Khan "put his birdie in my mouth, shook it and peed in my mouth." 51 Though the child's statement was corroborated by a semen stain on her jogging suit, the statement was hearsay and, generally, inadmissible for the truth of its contents. The trial judge ruled that the statement did not fall within the traditional hearsay exception for spontaneous declarations and excluded it from evidence.

The Supreme Court admitted the out-of-court statement into evidence, concluding that a hearsay statement of a child in a case involving sexual assault could be received into evidence provided that it met the requirements of "necessity" and "reliability." 52 The Court appeared particularly concerned that the inflexible hearsay exceptions were ill-suited to circumstances where a child complains of sexual assault, describing the hardships involved in requiring child witnesses to relive the traumatic event in a number of different settings ${ }^{53}$ and intimating a general concern that, without increased flexibility, otherwise relevant evidence could be lost to the trier of fact. Instead, McLachlin J. promoted a contextual approach by the trial judge in assessing the reliability of the out-of-court statement, focusing on "considerations such as timing, demeanour, the personality of the child, the intelligence

[1990] 2 S.C.R. 531 [Khan].

Ibid. at 534 .

Ibid. at 548 .

Ibid. at 540 . 
and understanding of the child, and the absence of any reason to expect fabrication in the

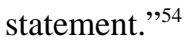

Two years later, the Supreme Court extended this principled approach to the general criminal law in R. v. Smith. ${ }^{55}$ Mr. Smith had been charged with murdering Aritha King and the theory of the Crown was that Smith was a drug smuggler who had travelled to Canada with King to obtain cocaine. The Crown tendered four telephone calls from King to her mother as evidence that King was with Smith immediately prior to her death. The evidence was necessary in its hearsay form because the declarant was deceased. At the outset of the Court's judgment, Lamer C.J.C. noted that Khan represented recognition that "the categorical approach to exceptions to the hearsay rule has the potential to undermine, rather than further, the policy of avoiding the frailties of certain types of evidence which the hearsay rule was originally fashioned to avoid" 56 and signalled "the triumph of a principled analysis over a set of ossified judicially created categories." ${ }^{57}$ Importantly, this movement towards a flexible approach was motivated by a realization that reliable and potentially true evidence was often excluded simply because it could not fit within the traditional conception of viva voce testimony and contemporaneous cross-examination. ${ }^{58}$ The rigidity of the law worked counter to the truth-seeking purpose of its trial system.

Chief Justice Lamer described highly flexible approaches when assessing the criteria of reliability and necessity. With respect to reliability, the trial judge should assess whether a "circumstantial guarantee of trustworthiness" was established with respect to the circumstances under which the statement was made. ${ }^{59}$ Likewise, Lamer C.J.C. gave the necessity criterion a highly flexible definition, suggesting that necessity will be found when the "direct evidence is not, for a variety of reasons, available." ${ }^{60}$ Much as in the case of Khan, the Supreme Court was motivated by a concern that the trier of fact should have access to all relevant, reliable evidence. In a manner reminiscent of those advocating for an evidentiary system of "free proof," Lamer C.J.C. opined that "it would be neither sensible nor just to deprive the jury of this highly relevant evidence on the basis of an arcane rule against hearsay, founded on a lack of faith in the capacity of the trier of fact properly to evaluate evidence of a statement, made under circumstances which do not give rise to apprehensions about its reliability." 61

The decision that followed, K.G.B., ${ }^{62}$ represents a significant triumph for the contextual approach of the principled exception and underscores the Supreme Court's continuing concern with allowing the trier of fact access to the most complete record of reliable evidence to determine "true facts.” The declarants in K.G.B. were available for testimony at trial but, during their respective testimonies, recanted prior statements made to police that had been video-recorded. The Crown attempted to tender the recorded statements for the

Ibid. at 547.

[1992] 2 S.C.R. 915 [Smith].

Ibid. at 928 .

Ibid. at 930 .

Ibid. at 935.

Ibid. at 933.

Ibid. at 934.

Ibid. at 935.

Supra note 6. 
truth of their contents but was unsuccessful at trial, the statements having been excluded under the traditional rule pertaining to prior inconsistent statements. In considering that rule, the Supreme Court of Canada continued its shift towards a flexible, contextual assessment of evidence admissibility, with Lamer C.J.C. suggesting that "the time has come for the orthodox rule to be replaced by a new rule recognizing the changed means and methods of proof in modern society., 63

Under the principled exception, Lamer C.J.C. allowed that prior inconsistent statements could be admitted into evidence, depending on "the comparative reliability of the prior statement and the testimony offered at trial." ${ }^{64}$ As one example of such a circumstance, the majority of the Court suggested that sufficient circumstances of trustworthiness would exist if the prior statement was made under oath or solemn affirmation, if the entire statement was video-recorded, and the opposing party has had opportunity to fully cross-examine the witness respecting the statement. ${ }^{65}$ Similarly, satisfaction of the necessity criterion was given significant flexibility, as the Court found that criterion satisfied when "evidence of the same value" was not available from the recanting witness or other sources. ${ }^{6}$ In K.G.B., the necessity requirement for the principled exception appeared only tenuously present, ${ }^{67}$ perhaps signalling the Supreme Court's increasing concern with ensuring a full record of reliable evidence for the trier of fact.

In the early examples of Khan, Smith, and K.G.B., one observes the Supreme Court's concern that the strict rules of exclusion and exception in the traditional hearsay approach hinder, rather than assist, the fact-finder from gaining a complete picture of a past event and coming to a conclusion of "true facts." The traditional approach to hearsay evidence was perceived to interfere with the dominant truth-seeking purpose of the criminal trial. Thus, the Court shifted the law from a categorical approach to the admission of evidence towards a more contextual approach of examining reliability, signifying a shift from a regulatory approach to evidence law to a more "free proof" approach. One observes that shift continue in later decisions with an expansion of the appropriate criteria to be considered when assessing the reliability criterion, beyond the circumstances under which the hearsay statement was made. In R. v. U. (F.J.), the majority of the Supreme Court opined that a trial judge could consider the content of the hearsay statement when assessing threshold reliability, suggesting that a hearsay statement may be reliable if there is a "striking similarity" between it and a statement of a separate declarant. ${ }^{68}$ Even greater latitude was afforded to the trial judge by the reasoning in Khelawon, where Charron J. suggested that it was appropriate, when considering the threshold reliability of a hearsay statement, to consider other corroborative or conflicting evidence. ${ }^{69}$

While the principled exception to the hearsay rule represents a shift from a categorical approach to the admission of hearsay evidence to a contextual approach, it is not a complete shift towards a "free proof" model. First, the trial judge retains ultimate discretion in 
determining whether the hearsay evidence satisfies the criteria of necessity and reliability and, accordingly, whether the trier of fact will be privy to the hearsay evidence. Admittedly, this distinction will be of greater significance in a jury trial as opposed to a trial by judge alone, where the trial judge simultaneously fulfills the role of trier of fact. Second, the traditional exceptions to the hearsay rule remain presumptively in place, though in rare cases hearsay evidence falling within a traditional exception may be excluded if lacking the criteria of necessity and reliability. ${ }^{70}$ Although the principled approach operates to supplement the traditional exceptions and, accordingly, likely affords the trier of fact greater access to relevant evidence, the law respecting hearsay evidence remains highly regulated. Finally, Paciocco's “rules of subordinated evidence” have continued relevance. Hearsay evidence that meets the criteria of necessity and reliability may nevertheless be excluded if it runs contrary to other evidentiary rules that are based on broader societal interests, such as the spousal incompetence rule. ${ }^{71}$ That all said, the development of the principled exception, and the Supreme Court's significant focus on the appropriate criteria to assess the reliability of hearsay evidence, perhaps underscores a perspective of the Court that evidence law should, as its primary purpose, be focused upon enhancing the truth-seeking ability of the trier of fact. When considering the criterion of "reliability," the evolution of the principled exception may therefore be viewed primarily as a product of concerns that current rules of evidence were inadequate to facilitate truth-seeking.

\section{B. RATIONALIZING THE NECESSITY CRITERION}

Case law at the Supreme Court has been almost exclusively devoted to clarifying and expanding the criteria used when determining whether a hearsay statement is reliable. By comparison, the Court has made very little effort in explaining the requirement of necessity. Instead, the Court has simply suggested that the necessity criterion should be interpreted "flexibly" and is effectively satisfied in situations where "evidence of the same value cannot be expected."72 Not surprisingly then, the Supreme Court has found that necessity has been satisfied in diverse situations, ranging from the death of a declarant, ${ }^{73}$ the incompetence of a child witness, ${ }^{74}$ the non-responsiveness of a child witness, ${ }^{75}$ the non-compellability of a coconspirator, ${ }^{76}$ the incompetence of a witness due to a spousal relationship with the accused, ${ }^{77}$ and the recanting of a prior statement by a witness. ${ }^{78}$ The reason why the hearsay statement was found to be "necessary" in those situations is perhaps obvious - the evidence contained in the prior statement was not available by other means at trial. In this respect, the principled exception to the hearsay rule assists the truth-seeking function of the trial process by admitting evidence that would not otherwise be available to the trier of fact.

While the principled approach augments the truth-seeking function of the trial process when evidence is necessary, requiring that hearsay evidence be necessary prior to its

R. v. Starr, 2000 SCC 40, [2000] 2 S.C.R. 144 at paras. 203-206 [Starr].

Couture, supra note 20 at para. 71.

K.G.B., supra note 6 at 743.

Smith, supra note 55; Starr, supra note 70; Khelawon, supra note 48; R. v. Blackman, 2008 SCC 37,

[2008] 2 S.C.R. 298.

Khan, supra note 50.

R. v. F. (W.J.), [1999] 3 S.C.R. 569.

R. v. Mapara, 2005 SCC 23, [2005] 1 S.C.R. 358 [Mapara].

Hawkins, supra note 7.

K.G.B., supra note 6; F.J.U., supra note 68; R. v. Devine, 2008 SCC 36, [2008] 2 S.C.R. 283. 
admission appears to have only a tenuous connection with the truth-seeking purpose of a criminal trial. It is a limiting factor on admissibility, meaning that otherwise reliable hearsay evidence will not be admitted to the trier of fact if it is unnecessary. As an example, a past and potentially reliable hearsay statement made by a witness who testifies at trial will only come to the attention of the trier of fact if that witness departs from the content of that prior statement. Otherwise, the hearsay statement is considered "unnecessary" and non-admissible. One may be inclined to question why this evidence should be excluded; if the evidence is reliable, it may be quite probative for the trier of fact to learn that the witness has been entirely consistent in their account of events. ${ }^{79}$ Accordingly, the adjudicator may not have access to full the range of reliable evidence when attempting to ascertain truth and, in some circumstances, the imposition of the necessity requirement may be seen to impede the truthseeking purpose.

Some may take the perspective that the requirement of necessity contributes to the tempered approach to truth-seeking. As has been implied by the Supreme Court, the requirement of necessity may have been imposed as a balancing of societal values, whether as a "rule of subordinated evidence" or as a "rule of practical exclusion." As a "rule of subordinated evidence," for example, the Supreme Court has suggested that necessity is required to satisfy two policy values: to ensure that the parties tender evidence in its best available form ${ }^{80}$ and to ensure that, where possible, an accused person is able to confront their accuser and test the reliability of their evidence via cross-examination. ${ }^{81}$

These policy concerns are insufficient on their own to justify the criterion of necessity as a requirement under the principled exception. First, the concern that the prosecution will no longer tender its best evidence is exaggerated. The argument is that, if hearsay could simply be admitted if sufficiently reliable, a potential strategy of the prosecution could be to avoid the cumbersome process of drawing evidence from potentially non-cooperative witnesses and simply tender the hearsay statement. However, evidence from a live witness is often more compelling than a recorded statement for the same reasons that hearsay evidence is difficult to assess. The trier of fact can observe the witness's demeanour during testimony and the witness's account, if it survives vigorous cross-examination, may be strengthened by the trial process. From the perspective of the prosecution, it may often be preferable to call viva voce evidence rather than rely on a hearsay statement.

Second, while the right of an accused to confront his or her accuser is a significant right in our criminal legal system, it is not an absolute right. As noted earlier, hearsay evidence such as business records and certificates of analysis are often admitted for reasons of both reliability and efficiency. Moreover, many of the traditional exceptions have no basis in necessity but are rather admitted due to their reliability, such as the spontaneous utterance exception. Finally, while both policy concerns are legitimate, if perhaps exaggerated, one must question whether these concerns should dictate the admissibility of otherwise relevant

While probative, other evidentiary rules, such as the rule against prior consistent statements, also play a significant role in prohibiting this type of evidence from being tendered. This point is further developed when considering the policy considerations related to "rules of subordinated evidence" and "rules of practical exclusion" in the discussion that follows. 
evidence. If the concern is that a party has not called its best evidence or has strategized to allow its evidence to be untested by cross-examination, perhaps the better approach is to allow the trier of fact access to the hearsay statement but invite or require the trier of fact to draw an adverse inference when weighing the evidence if admission of the statement was "unnecessary."

It may also be argued that the necessity requirement is a "rule of practical exclusion," imposed as an effort to improve trial efficiency by limiting the admission of collateral, corroborative, or simply "oath-helping" hearsay statements unless the evidence is not available in alternative, better forms. One may, however, question whether greater certainty and efficiency is gained by imposing a necessity requirement. Under the principled exception, the parties must wait and see whether the evidence becomes necessary during the course of a trial, rather than being able to assess hearsay statements for reliability and tender reliable evidence as a matter of course. Without the necessity requirement, the principled approach could be conducted efficiently by simply using a pre-trial voir dire directed at assessing the reliability of the statement. Other complementary or competing evidentiary rules, such as the rule against prior consistent statements, could continue to be applied during the course of proceedings to ultimately prevent admission. Instead, under the current approach, the voir dire process must often be engaged mid-trial once necessity becomes an issue, on occasion interrupting and complicating the natural course of calling evidence.

The necessity requirement is more comfortably rationalized when one considers the communicative purpose of evidence law. As suggested earlier, an adjudicator's verdict will fail to achieve acceptance by the accused and the public if it is implausible given the evidence presented at trial or if based on implausible evidence. Nesson suggests that one explanation for the traditional hearsay exclusionary rules is that they help to produce both an immediate and continuing acceptance of a verdict. Generally, requiring a declarant to testify in person places the juror in a better position than the general public to assess the evidence; the public accordingly defers to the judgment of the fact-finder and immediately accepts the verdict. ${ }^{82}$ That superior evidential basis for a verdict promotes its immediate acceptance. That said, the public's willingness to accept a jury's conclusion may be undermined if the public knows that the jury has not considered all relevant evidence, including hearsay evidence. For that reason, Nesson argues that the traditional hearsay rule is rationalized by the interest in achieving the continued acceptance of verdicts. By limiting the admission of hearsay evidence to specific circumstances of exception, the hearsay rules protect the stability of judgments by allowing the admission of some forms of hearsay evidence but limiting the instances where an adjudicator bases their verdict on a hearsay statement that may be later discredited. ${ }^{83}$ As an example, Nesson suggests that our admission of dying declarations is not owed to inherent reliability in such statements, but because they "pose little risk of destabilizing the judgment" in the future. ${ }^{84}$ The chance that the declarant will contradict the hearsay statement at a later date is clearly remote. 
The necessity requirement under the principled approach to hearsay evidence achieves a similar balance in this communicative function of evidence law. It broadens the evidential base to include all evidence meeting a threshold of reliability, but limits the admission of hearsay statements to only those situations where admission of the statement is necessary to introduce evidence of comparable value to the trier of fact. Through the principled approach, we communicate to both the accused and the general public that we are open to considering all relevant evidence, but that we prefer and require evidence to be presented in person through viva voce testimony. Moreover, by imposing the necessity requirement, consideration of hearsay evidence is limited to those instances where future, credible recantation of that statement is minimized. It cannot be argued that the traditional process of calling viva voce evidence was not attempted. The adjudicative record is thereby assured of a greater guarantee of reliability and a reduced future contestability than the information available to the general public. In that sense, the necessity requirement may promote immediate and continued deference to the trial verdict.

The necessity requirement also contributes to the epistemic and ethical justification of the decision-maker. A party is generally unable to contemporaneously cross-examine the declarant of a hearsay statement and, in circumstances such as the death of the declarant, may never be able to cross-examine the declarant. The ability to cross-examine a declarant of a statement is typically sanctified as a means of testing the reliability of that statement but it also assists the epistemic deliberation of the adjudicator by challenging the defeasibility of inferences drawn by the adjudicator with respect to that evidence. ${ }^{85}$ The reasoning of an adjudicator respecting a specific piece of evidence is accordingly better tested and more epistemologically justifiable if evidence is subject to cross-examination. Moreover, ensuring that an accused has adequate opportunity to test the evidence tendered assures the adjudicator that the accused person has had a fair opportunity to participate in the criminal process. By imposing a condition of necessity when admitting hearsay evidence, the principled exception limits the circumstances where an accused is unable to adequately test tendered evidence to only those circumstances considered "necessary" and, accordingly, limits those instances where the epistemic and ethical justification for the adjudicator's verdict may remain unsatisfied. The necessity requirement is therefore most appropriately viewed as providing a balance between the truth-seeking purpose of the trial process and those purposes relating to its communicative function and role in regulating trial deliberation.

\section{The ReleVance of THe VoIr Dire Procedure}

The procedure for tendering hearsay evidence under the principled exception is stratified and highlights the separation between the trial judge and the trier of fact. ${ }^{86}$ The role of the trial judge can be described as a screening role. If a party wishes to tender a hearsay statement for the truth of its contents, the trial judge commences a voir dire to examine whether, on a balance of probabilities, the hearsay statement satisfies the criteria of reliability and necessity. If the trial judge is satisfied that the statement is sufficiently reliable and necessary, the statement may then be admitted into evidence for consideration by the trier of fact. The conduct of this procedure may, in practice, be more formalized where an accused 
is tried by jury than where an accused is tried by a judge sitting alone, as that judge sits simultaneously as the trier of fact.

It is difficult to rationalize the voir dire process as furthering the truth-seeking function of the trial process. In cases where the accused is tried by jury, the jury is only privy to the evidence following the conduct of the voir dire. This stratified procedure can only be rationalized as contributing to truth-seeking if one presumes that juries are cognitively less sophisticated than a trial judge sitting alone - a point that is contested from several perspectives in evidence law scholarship. As an example from an advocate for a system of "free proof," Todd Pettys argues that juries are fully capable of making rational decisions when considering evidence, and that it offends a juror's autonomy and rationality to conceal evidence based on how that juror may use it. ${ }^{87}$ As an example from an advocate for a system of increased regulation, Frederick Schauer suggests that, without further empirical research, we should not readily assume that "judges are less prone than juries to the cognitive and decision-making failures" we are concerned about with jurors. ${ }^{88}$ Given this debate in the literature, an assumed distinction between the cognitive abilities of judges and juries provides an unsatisfactory justification of the voir dire process as furthering the truth-seeking purpose of evidence law.

There appears to be further disconnect between the voir dire process and truth-seeking in the situation of a trial judge sitting alone. The trial judge will, in such a circumstance, both conduct the voir dire to determine admissibility and later weigh the evidence as trier of fact if that evidence is admitted. While, at least theoretically, the hearsay evidence will not factor into the judge's deliberation if not admitted, one must question whether knowledge of that evidence practically affects the deliberative process. Unlike the jury example, the trial judge is irreversibly aware of the hearsay statement. In a trial before a judge sitting alone, the formal voir dire process seems irrelevant and is inadequately explained when conceptualizing the principled approach as solely furthering the truth-seeking purposes.

The voir dire process is better rationalized when considering the communicative function of evidence law. The accused and the public are very rarely privy to the deliberative process of a judge or jury. A judge may seldom, and a Canadian jury will never, give reasons as to how specific pieces of evidence affected the deliberative process. If the court has weighed evidence that is popularly or traditionally considered less reliable, such as a hearsay statement, a failure to explain how and why that evidence was considered at trial may undermine both the immediate and continuing acceptance of the verdict by the accused and general public. Conversely, a public statement as to why the trier of fact was entitled to consider that evidence may help bolster the ultimate acceptability of the verdict. This purpose may be effectively achieved by an explicit decision following the conclusion of the voir dire.

The voir dire process can also be rationalized by considering evidence law as a means to promote epistemic and ethical justification on the part of the adjudicator, most significantly in the context of the trial judge sitting alone. By having to publicly and rationally articulate

$87 \quad$ Supra note 13 at 500, 505.

88 Frederick Schauer, “On the Supposed Jury-Dependence of Evidence Law” (2006) 155 U. Pa. L. Rev. 165 at 188. 
the reasons for admitting a hearsay statement at the close of a voir dire, the trial judge is forced to challenge their reasons as to why the hearsay statement meets the threshold of reliability, promoting greater epistemic justifiability. In a manner similar to the necessity requirement, a formalized voir dire process also assures the adjudicator that the accused has been treated fairly and that the appropriate level of caution has been taken when dealing with presumptively unreliable evidence. In this context, the formal voir dire process therefore has continued relevance, even when the accused is tried by a judge sitting alone, and formal processes have the tendency to be relaxed. While its role in furthering the truth-seeking purpose of evidence is often subject to assumptions, the voir dire process can be more fully rationalized by considering the role of evidence law as a communicative medium and as a means to regulate the deliberation of the adjudicator.

\section{CONCLUSION}

A criminal trial and its rules of evidence and procedure are traditionally considered as means to determine the truth of past events. Truth-seeking, however, only provides a partial explanation for specific rules of evidence. While truth-seeking is an important, and perhaps primary, purpose of evidence law, one must also consider the role of evidence law and trial procedure in communicating the acceptability of verdicts and in regulating an adjudicator's deliberation, from an epistemic and ethical perspective. In this respect, the development of the principled exception to the exclusion of hearsay evidence is telling. Canadian treatment of hearsay evidence has changed significantly in the preceding 20 years, with the Supreme Court paying considerable attention in fostering a contextual approach to assessing the reliability of hearsay evidence and, thereby, enhancing the truth-seeking abilities of the trial process. Though only loosely connected with the truth-seeking purpose, the requirement of necessity and the formal voir dire process enhance the principled approach by furthering the purposes of evidence law related to communication of acceptable verdicts and regulation of trial deliberation. By attempting a balance between the multiple purposes of evidence law, the principled approach has been designed to seek more than "truth.” 